\title{
Kucing Hoki dalam Pandangan Etnis Tionghoa
}

\author{
Micshir Leen, Eko Harry Susanto, Nigar Pandrianto \\ micshirleen.915150052@stu.untar.ac.id,ekohs@untar.ac.id,nigarp@untar.ac.id
}

Fakultas Ilmu Komunikasi Universitas Tarumanagara

\begin{abstract}
Lucky Cat are considered to be a symbol of luck for Chinese Ethnic and are often found in shops. Inter-cultural communication that is interwoven in the culture of Lucky Cat is where people who have economic, political, religious and other backgrounds try to join the culture of Lucky Cat. Symbols will have meaning if someone puts value on it, especially Lucky Cat, which means a symbol of good luck that has been agreed upon. This study seeks to reveal what caused the culture of Lucky Cat to spread, the different meanings of the Lucky Cat and the different objectives of using Lucky Cat. In conducting this, researchers used in-depth interview techniques, observation, literature study. The conclusion obtained from this study are the Lucky Cat is a Chinese Ethnic culture because it contains cultural characteristics and the spread of the Lucky Cat culture due to various channels (family, friends, religion and others). One's belief determines the meaning of the Lucky Cat so that the value generated will encourage their communication actions and the impact on the Lucky Cat is luck for those who believe it. As well as Lucky Cat is a culture that continues to be adapted to the needs.
\end{abstract}

Keywords: Lucky Cat, Chinese Ethnic, Culture and Symbols

\begin{abstract}
Abstrak
Kucing Hoki dianggap menjadi simbol keberuntungan bagi Etnis Tionghoa dan sering sekali ditemukan pada tempat usaha atau toko-toko. Komunikasi antar budaya yang terjalin pada budaya Kucing Hoki ini adalah dimana orang-orang Etnis Tionghoa yang mempunyai latar belakang ekonomi, politik, kepercayaan dan lainnya berusaha bergabung dengan menjalankan budaya Kucing Hoki. Simbol akan memiliki makna jika seseorang menaruh nilai terhadapnya khususnya Kuicng Hoki yang mempunyai arti sebagai simbol keberuntungan yang telah disepakati bersama. Penelitian ini berusaha untuk mengungkap apa yang menyebabkan budaya Kucing Hoki tersebar, pemaknaan yang berbeda dari Kucing Hoki, serta tujuan yang berbeda dari penggunaan Kucing Hoki. Dalam melakukan penelitian ini peneliti menggunakan teknik wawancara mendalam, observasi, studi kepustakaan. Kesimpulan yang didapatkan dari penelitian ini adalah Kucing Hoki merupakan suatu budaya Etnis Tionghoa karena didalamnya mengandung karakteristik budaya serta penyebaran budaya Kucing Hoki disebabkan oleh berbagai saluran (keluarga, teman, agama dan lainnya). Kepercayaan seseorang menentukan pemaknaan pada Kucing Hoki sehingga nilai yang ditimbulkan akan mendorong tindakan komunikasi serta dampak yang ada pada Kucing Hoki yaitu keberuntungan bagi yang mempercayainnya. Kucing Hoki juga merupakan budaya yang terus berkembang dengan kebutuhan.
\end{abstract}

Kata Kunci: Kucing Hoki, Etnis Tionghoa, Budaya dan Simbol

\section{Pendahuluan}

Komunikasi dan kebudayaan merupakan dua aspek yang tidak dapat terpisahkan dari kehidupan masyarakat. Bahkan Samovar \& Porter (dalam Tamburian, 2018) mengatakan bahwa budaya bertanggung jawab atas seluruh pembendaharaan perilaku komunikatif dan makna yang dimiliki setiap orang. Dalam pembentukkan makna 
tersebut dapat dilihat dari pesan yang ditukarkan yakni komunikasi verbal yang secara langsung ataupun komunikasi non-verbal secara tidak langsung. Tanda, simbol dan kode merupakan ketiga unsur dari pesan non-verbal yang memiliki makna lebih lanjut. Simbol menunjukkan kehadiran pesan dalam bentuk suatu benda dan biasanya mengandung makna dan adanya kepercayaan didalamnya (Liliweri, 2003).

Di Indonesia terdapat berbagai macam suku dengan budaya yang berbeda-beda, salah satunya adalah Etnis Tionghoa yang memiliki banyak simbol dalam kebudayaannya. Salah satu simbol kepercayaan etnis Tionghoa adalah Kucing Hoki. Simbol tersebut merupakan warisan yang terus dilestarikan. Kucing Hoki kerap dikaitkan dengan sebuah kepercayaan mendatangkan rezeki atau kemakmuran dan selalu digunakan saat berwirausaha. Selain itu, Kucing Hoki merupakan budaya minor tetapi merupakan bagian penting dari sebuah budaya. Seiring berkembangnya zaman, penggunaan Kucing Hoki yang awalnya digunakan untuk memanggil rezeki kemudian bertambah memiliki makna lain. Rumusan masalah penelitian ini yakni pembentukan budaya dari Kucing Hoki; perbedaan pemaknaan dari Kucing Hoki, serta tujuan yang berlainan dari penggunaan Kucing Hoki pada masyarakat Etnis Tionghoa. Penelitian ini bertujuan untuk menggali serta mengetahui bagaimana pandangan masyarakat Etnis Tionghoa terhadap Kucing Hoki.

Menurut Putra, komunikasi antar budaya atau lintas budaya adalah komunikasi yang terjadi diantara orang-orang yang mempunyai kebudayaan yang berbeda (2016). Budaya selalu berkenaan dengan cara manusia hidup. Budaya juga berkenaan dengan sifat-sifat dari obyek-obyek materi yang memainkan peranan penting itu. Maka terdapat dua unsur yaitu budaya material (obyek materi yang dihasilkan dan digunakan manusia berupa instrument) dan budaya non-material (bentuk gagasan atau ide-ide) (Liliweri, 2003). Pewarisan budaya Heriter la Theory yakni budaya diturunkan dari generasi ke generasi, bagaimana pihak yang mendominasi sehingga pihak yang lain dengan pasrah mengikuti dan Acquirer La Culture Theory di mana sisi kelompok kebudayaan yang berupaya menciptakan variasi budaya dari adaptasi lingkungan baru sehingga ritual budaya masa lalu termodifikasi (Putra, 2016).

Karakteristik budaya (Samovar, 2010) yaitu budaya itu dipelajari, budaya itu dibagikan, budaya itu diturunkan dari generasi ke generasi, budaya itu didasarkan pada simbol, budaya itu dinamis dan budaya itu sistem yang teintegrasi. Selain itu, pada budaya juga terdapat unsur kebiasaan dan kepercayaan. Penelitian ini berusaha untuk melihat pandangan etnis Tionghoa mengenai Kucing Hoki, bagaimana simbol tersebut disepakati dan memiliki makna bagi personal dan masyarakat/kolektif (Little John, 2009). Simbol merupakan representasi dari fenomena sehingga menghasilkan simbol konkret yang merupakan simbol yang mepresentasikan benda dan simbol arbiter yang merepresentasikan suatu pemikiran atau ide (West \& Turner, 2008). Konsep mengenai pandangan. Menurut Jalaluddin Rakhmat (2012) persepsi atau pandangan diartikan sebagai pengalaman tentang obyek, peristiwa, atau hubungan-hubungan yang diperoleh dengan menyimpulkan informasi dan menafsirkan pesan. Dalam Samovar diterangkan mengenai berbagai bentuk cara pandang yaitu dengan agama, sekularisme dan spiritual.

\section{Metode Penelitian}

Peneliti menggunakan pendekatan kualitatif yang bersifat deskriptif sehingga pendekatan ini berusaha menjelaskan fenomena yang terjadi dan membahasnya secara terperinci mengenai kebudayaan Kucing Hoki tersebut. Peneliti menggunakan metode 
penelitian fenomenologi, yang berusaha mengungkap dan mempelajari serta memahami suatu fenomena berserta konteksnya yang khas dan unik yang dialami oleh individu hingga tataran "keyakinan" individu yang bersangkutan. Dengan demikian, saat berusaha mempelajarinya dan memahami harus berdasarkan sudut pandang dan keyakinan langsung dari individu yang bersangkutan sebagai obyek yang mengalami langsung (Herdiansyah, 2014). Kucing Hoki ini merupakan fenomena atau peristiwa unik dalam masyarakat etnis Tionghoa dalam memahami suatu pengalaman dan pandangan mereka terhadap budaya tersebut. Subyek dalam penelitian ini adalah pedagang dan masyarakat etnis Tionghoa yang menggunakan Kucing Hoki. Narasumber berdomisili di Jakarta, memiliki latar belakang (usia, tempat asal, serta keyakinan) yang berbeda. Penelitian ini juga melibatkan budayawan Tionghoa dan ahli dalam kebudayaan Tionghoa (Sinolog). Sementara obyek penelitian adalah Kucing Hoki dan pandangan masyarakat etnis Tionghoa terhadap Kucing Hoki. Data primer yang diperoleh dari hasil wawancara dengan subyek penelitian dan observasi ke tempat subyek penelitian. Sedangkan data sekunder diperoleh dari studi kepustakaan melalui buku-buku atau karya ilmiah yang membahas mengenai budaya Tionghoa serta sumber informasi online

Teknik dalam mengolah data dan menganalisisnya dengan menggunakan model interaktif Huberman dan Miles. Terdapat tiga tahap dalam model ini pertama, peneliti mengumpulkan data dari observasi serta hasil wawancara yang diperoleh. Kedua, dari hasil yang didapatkan kemudian tahap pemilihan, pemusatan perhatian kepada data mana yang harus difokuskan. Yang terakhir yaitu penyajian data secara sistematis sehingga mendapatkan kesimpulan mengenai pandangan Etnis Tionghoa terhadap Kucing Hoki (Susanto, 2018). Untuk melakukan keabsahan data yang telah dilakukan dengan menggunakan metode triangulasi. Dalam penelitian ini peneliti menggunakan triangulasi sumber dimana membandingkan hasil-hasil wawancara yang dilakukan dengan sumber (Moleong, 2009).

\section{Hasil Temuan dan Diskusi}

Kucing Hoki merupakan sebuah patung berbentuk kucing yang sedang melambaikan tangan kanan atau kirinya ke depan dan ke belakang. Kucing Hoki atau Zao Chai Mao merupakan lambang atau simbol keberuntungan bagi orang Tionghoa. Kucing Hoki dipercaya mampu membuat usaha yang digeluti makmur dan selalu kedatangan rezeki. Kucing dianggap sebagai hewan mistis karena kemampuannya yang bisa melihat dalam gelap serta dapat mengusir roh jahat atau pengaruh jelek (Eberhard, 1996). Selain itu, kucing juga dapat meramal seperti kapan hujan turun (Ong, 1996). Bagi kebudayaan Tionghoa, hujan merupakan pertanda baik dikarenakan mendatangkan rezeki atau berkah (Seng, 2007). Kucing Hoki memiliki banyak jenis warna. Warna yang sering ditemukan adalah emas yang berarti membawa keberuntungan, kemakmuran dalam hidup. Tangan Kucing Hoki yang terangkat memiliki makna yang berbeda. Jika tangan kanan terangkat maka maknanya adalah memanggil keuntungan namun jika tangan kiri terangkat artinya memanggil pelanggan. Namun jika kedua tangannya terangkat mengandung makna proteksi atau kemakmuran.

\section{Pengetahuan mengenai Budaya Kucing Hoki}

Budaya menjadi suatu bagian masyarakat, pada bentuknya budaya dapat berupa benda yang bernilai seperti Kucing Hoki. Setiap hal atau benda yang memiliki sebuah 
makna bagi seseorang atau dianggap suatu hal yang positif akan terus dilestarikan. Pada bagian ini peneliti mewawancarai beberapa narasumber untuk mengetahui darimana mereka mengetahui budaya Kucing Hoki tersebut, berikut tabel hasil wawancara yang telah diolah oleh peneliti.

Tabel 1. Pengetahuan mengenai Kucing Hoki

\begin{tabular}{lll}
\hline No. & Rekomendasi & Deskripsi \\
\hline 1. & Keluarga & $\begin{array}{l}\text { Mengetahui dari leluhur, orang tua yang terlebih dahulu } \\
\text { mempercayai, dari sanak saudara. }\end{array}$ \\
\hline 2. & Teman & $\begin{array}{l}\text { Direkomendasikan oleh teman-teman seperdagangan atau } \\
\text { yang membuka usaha, khususnya etnis Tionghoa. }\end{array}$ \\
\hline 3. & Agama & $\begin{array}{l}\text { Lewat agama khususnya agama Buddha, budaya Kucing Hoki } \\
\text { dipergunakan dan dipercaya. }\end{array}$ \\
\hline 4. & Lain-lain & $\begin{array}{l}\text { Melihat dari tempat usaha Etnis Tionghoa lainnya yang } \\
\text { memakai dan menjadi terdorong untuk memakainya atau ikut- } \\
\text { ikutan atau tren. }\end{array}$ \\
\hline
\end{tabular}

Sumber: dokumentasi peneliti (2018)

Berdasarkan tabel di atas, budaya Kucing Hoki disebarkan melalui keluarga, teman, agama dan lain-lain. Ditemukan bahwa penyalur-penyalur tersebutlah yang berperan dalam menyebarkan budaya Kucing Hoki. Enam dari sembilan narasumber yang diwawancarai mengetahui bahwa Kucing Hoki berasal dari Tiongkok dan sisanya mengetahuinya dari Jepang.

\section{Kucing Hoki Membawa Keberuntungan}

Manusia dan simbol tidak akan terpisah. Dari simbol tersebut lahirlah makna yang dipercaya oleh manusia. Sesuatu yang dipercaya oleh seseorang akan menimbulkan makna yang besar dalam kehidupan mereka, begitupun tentang pandangan mereka mengenai Kucing Hoki dalam hal kepercayaan, makna, dan efek yang terjadi. Pemaknaan seseorang yang akan menimbulkan kesan terhadap sesuatu atau kekuatan. Bagi yang mempercayainya Kucing Hoki membawa keberuntungan bagi mereka. Berikut merupakan tabel dari narasumber terkait kepercayaan mereka terhadap Kucing Hoki serta apa yang terjadi saat pemaknaan itu terbentuk.

Tabel 2. Kepercayaan Terhadap Kucing Hoki

\begin{tabular}{|c|c|c|}
\hline No. & Efek Kepercayaan & Deskripsi \\
\hline 1. & Percaya & $\begin{array}{l}\text { Menghasilkan sebuah makna atau dampak yaitu Kucing Hoki } \\
\text { terbukti membawa keberuntungan bagi usaha atau hidup } \\
\text { mereka. Ditandai dengan barang yang selalu yang terjual. } \\
\text { Pergerakan tangan Kucing Hoki yang paling penting, karena } \\
\text { dapat membuat barang laku, serta warna emas setelahnya. }\end{array}$ \\
\hline 2. & Setengah Percaya & $\begin{array}{l}\text { Efek yang dihasilkan tidak banyak seperti mereka yang } \\
\text { mempercayainya. Tidak berpatok dengan Kucing Hoki saja. } \\
\text { Pergerakan tangan serta warnanya yang membuat Kucing } \\
\text { Hoki menjadi simbol keberuntungan. }\end{array}$ \\
\hline 3. & Tidak Percaya & $\begin{array}{l}\text { Tidak ada efek yang terjadi sama sekali hanya sebagai hiasan } \\
\text { saja, tidak mengandung makna apapun. Lebih mempercayai } \\
\text { usaha yang dikerjakan serta pada musim yang sedang terjadi } \\
\text { (Natal, Lebaran, Tahun Baru dan lainnya.) }\end{array}$ \\
\hline
\end{tabular}

Sumber: Dokumentasi Peneliti (2018) 
Kucing Hoki Membawa Hal Baik Lainnya

Kucing Hoki biasanya ditemukan di toko-toko dengan tujuan untuk memanggil rezeki atau keuntungan bagi yang memasangnya. Tetapi peneliti menemukan hal unik lainnya dari penggunaan Kucing Hoki. Bahkan ditemukan bahwa Kucing Hoki tidak hanya digunakan untuk tempat usaha saja tetapi di rumah. Berikut merupakan tabel dari tujuan penggunaan Kucing Hoki atau makna lain dari Kucing Hoki tidak hanya untuk memanggil rezeki.

Tabel 3. Tujuan Pengguaan Kucing Hoki

\begin{tabular}{lll}
\hline No. & Tujuan Penggunaan & Deskripsi \\
\hline 1. & $\begin{array}{l}\text { Untuk Kesehatan \& } \\
\text { Panjang Umur }\end{array}$ & $\begin{array}{l}\text { Tulisan yang ditempatkan pada Kucing Hoki yang berarti } \\
\text { Fu dapat berarti luas yakni untuk kesehatan dan panjang } \\
\text { umur }\end{array}$ \\
\hline 2. & Untuk Penolak Bala & $\begin{array}{l}\text { Kucing merupakan hewan mistis karena dapat melihat hal } \\
\text { yang kasat mata dan melihat dalam gelap sehingga } \\
\text { dianggap dapat menolak bala atau perbuatan jahat yang } \\
\text { mau mendatangi }\end{array}$ \\
\hline 3. & Memanggil & $\begin{array}{l}\text { Tangan kucing yang bergerak seakan memanggil atau } \\
\text { mengusap wajahnya atau mandi kucing dianggap dapat } \\
\text { meramal akan datang pelanggan }\end{array}$ \\
\hline Pelanggan & Untuk Hiasan \& & $\begin{array}{l}\text { Pergerakan tangan Kucing Hoki membuat adanya energi } \\
\text { yang dinamis menjadikan suasana hidup dan Kucing Hoki } \\
\text { untuk mempercantik ruangan }\end{array}$ \\
\hline
\end{tabular}

Sumber: Dokumentasi Peneliti (2018)

\section{Karakteristik Budaya Kucing Hoki}

Budaya Kucing Hoki merupakan hal yang sudah lama terjadi dan dilestarikan oleh Etnis Tionghoa, dan terdapat berbagai faktor mengenai karakteristik dari budaya Kucing Hoki sendiri, bagaimana budaya tersebut bisa terus ada sampai sekarang. Menurut Samovar (2010) terdapat beberapa karakteristik budaya. Dalam Kucing Hoki sendiri terdapat karakteristik budaya itu sendiri yaitu budaya itu diturunkan dari generasi ke generasi. Ditemukan bahwa budaya serta nilai dalam Kucing Hoki diwariskan dari orang tua, sanak saudara, bahkan leluhur. Jika ditemukan bahwa budaya tersebut memiliki nilai-nilai penting bagi suatu masyarakat maka hal tersebut akan dan terus diturunkan dari satu generasi ke generasi. Nilai yang terdapat pada Kucing Hoki adalah pembawa keberuntungan bagi pemakainya. Maka Heriter la Culture Theory terbukti benar karena menjelaskan mengenai konsep pewarisan budaya. Seseorang yang menggunakan Kucing Hoki adalah orang yang didominasi karena keyakinan dan kepasrahan atas ajaran budaya yang telah lama ada dan didorong oleh keluarga sehingga membuat Kucing Hoki terus dilestarikan (Putra, 2016).

Kedua, budaya dipelajari lewat berbagai pembelajaran. Pembelajaran informal ditemukan dalam budaya Kucing Hoki yang terdiri dari interaksi, pengamatan dan imitasi. Pengamatan beberapa informan mengenai toko-toko yang mempunyai Kucing Hoki membawa mereka untuk ikut menggunakannya juga atau mengimitasinya. Lalu, adanya interaksi yaitu terlihat dari beberapa informan memakai Kucing Hoki akibat adanya interaksi verbal (diberi tahu) dan non-verbal (melihat) (Liliweri 2003). Ketiga, budaya dibagikan. Kucing Hoki dibagikan diantara anggota suatu budaya, keluarga, media, teman dan lainnya. 
Kepercayaan dann Cara Pandang Menimbulkan Berbagai Pemaknaan

Sebuah kepercayaan memberikan interpretasi kepada Kucing Hoki, bagi yang mempercayainya akan menimbulkan suatu makna dan memberikan dampak sehingga tidak dapat lepas darinya (Liliweri 2003). Seseorang yang mempercayai Kucing Hoki menaruh makna dan nilai terhadap hal tersebut akan menentukan tindakan komunikasi mereka (Samovar, 2010). Terlihat dari tindakan mereka yang akan memasang Kucing Hoki dan tidak membiarkan gerakan tangannya mati. Saat kepercayaan itu terbentuk maka makna juga terbentuk, makna yang ditimbulkan disini adalah bagaimana seseorang menilai Kucing Hoki sebagai dianggap benar dalam hal membawa keberuntungan bagi usaha mereka. Saat tidak ada makna yang terbentuk maka tidak akan terjadi apapun. Sehingga kepercayaan pribadi seseorang akan menimbulkan makna personal atau makna konotatif (Little John, 2009), yakni pada warna emas yang diyakini sebagai pemanggil uang, gerakan tangan Kucing Hoki dimaknai sedang memanggil rezeki untuk datang. Bagi mereka yang memiliki makna konotatif maka akan menimbulkan dampak tetapi bagi mereka yang tidak memiliki makna personal akan melihatnya sebagai makna denotatif yakni Kucing Hoki hanya sebuah patung kucing yang sedang menggerakan tangannya. Serta hanya sebagai kebiasaan saja yang dilakukan berulang-ulang tanpa adanya makna tertentu (Liliweri, 2003).

Selain itu makna juga ditimbulkan melalui cara pandang. Menurut Samovar (2010), pandangan atau persepsi yang tersimpan pada manusia adalah berbentuk kepercayaan dan nilai. Sedangkan Jalaluddin Rakhmat pandangan atau persepsi diartikan sebagai pengalaman tentang obyek, peristiwa atau hubungan-hubungan yang diperoleh dengan menyimpulkan informasi dan menafsirkan pesan. Pada Kucing Hoki, seseorang yang memiliki kepercayaan terhadapnya dan merasakan dampak darinya akan menyimpan nilai atau makna yang lebih dan mendapatkan pengalaman karena dampak dari Kucing Hoki tersebut membuat seseorang menyimpulkan bahwa Kucing Hoki adalah jiamt yang ampuh dalam budaya Tionghoa untuk memanggil keberuntungan. Selain itu agama juga menjadi bagian dalam membentuk cara pandang, agama mengikat orang bersama-sama dan memelihara cara pandang budaya selama bertahun-tahun (Samovar 2010). Agama Buddha berperan penting dalam membuat kepercayaan pada Kucing Hoki sehingga adanya nilai atau makna yang terbentuk. Sehingga benar bahwa agama Buddha dapat mengikat pengikutnya untuk mempercayai Kucing Hoki.

Simbol merupakan sesuatu yang sudah disepakati bersama oleh masyarakat sehingga ada makna yang terjalin didalamnya (West \& Turner, 2008). Kucing Hoki disepakati menjadi simbol keberuntungan bagi Etnis Tionghoa. Serta sifat simbol ditemukan dalam Kucing Hoki (Mulyana, 2010), pertama sifat simbol yang sembarang atau manasuka dalam artian semua dapat dijadikan simbol asal disepakati bersama. Patung kucing yang merupakan benda disepakati menjadi Kucing Hoki simbol keberuntungan. Sifat kedua adalah simbol pada dasarnya tidak memiliki makna, tetapi kitalah yang memberikan makna. Kucing Hoki yang awalnya hanya benda mati menjadu bermakna saat ada kepercayaan yang ditaruhkan didalamnya yakni simbol pembawa keberuntungan. Tangannya yang bergerak diartikan sebaga memanggil dan warna emas bermakna rezeki. Kucing Hoki juga merupakan simbol konkret atau simbol yang merepresentasikan benda. Sifat simbol yang ketiga adalah simbol itu bervariasi dari satu konteks ke konteks lain atau dari budaya ke budya lainnya. Kucing Hoki memiliki nama lain yakni Zhao Cai Mao (bahasa Mandarin), Maneki Neko (bahasa Jepang) dan Lucky Cat (bahasa Inggris). Sesuai dengan budaya yang 
ditempatkan asal disepakati bersama, di Indonesia sendiri sebutannya adalah Kucing Hoki.

Selain itu karakteristik budaya yang dinamis ditemukan dalam Kucing Hoki. Yang dimaksudkan oleh Alo Liliweri (2003) budaya berkembang atau dinamis atau tumbuh menjadi luas dan bertambah. Kucing Hoki yang awalnya hanya merupakan simbol keberuntungan mengalami perkembangan makna lainnya serta kegunaannya. Hal ini terjadi karena adanya evolusi budaya atau penyesuaian budaya yang tidak dapat dihindarkan karena adanya faktor kebutuhan manusia yang dinamis serta perkembangan nalar rasional manusia dalam menghadapi tantangan hidup (Putra, 2016). Kebutuhan manusia tersebut maka terciptanya tujuan penggunaan Kucing Hoki yang tidak hanya digunakan untuk membawa keberuntungan namun penolak bala, memanggil kesehatan, hiasan dan lainnya yang membawakan rasa aman untuk manusianya.

\section{Simpulan}

Kucing Hoki merupakan salah satu budaya etnis Tionghoa. Kucing Hoki memiliki karakteristik budaya. Penyebaran budaya Kucing Hoki pada etnis Tionghoa dilakukan lewat banyak hal yakni melalui keluarga, teman, agama dan lainnya yang menimbulkan rasa ingin menggunakan Kucing Hoki. Selain itu kepercayaan seseorang menentukan berbagai pemaknaan pada Kucing Hoki. Seseorang yang mempercayai nilai budaya tersebut mendapatkan dampak dari pemaknaannya.

Perbedaan tujuan penggunaan dari Kucing Hoki disebabkan oleh perkembangan budaya serta terjadinya penyesuain budaya yang disangkutpautkan dengan kebutuhan yang terjadi pada manusia.

Budaya merupakan warisan penting bagi peradaban manusia. Penelitian ini diharapkan dapat menyadarkan masyarakat mengenai sebuah budaya yang membentuk pola komunikasi suatu masyarakat yang ada. Budaya yang ada harus terus diturunkan dan menjaga nilai-nilai esensi yang membangun dari budaya tersebut. Penelitian ini diharapkan dapat membangun rasa toleransi dan saling menghargai perbedaan yang kerap muncul dalam bermasyarakat.

\section{Ucapan Terima Kasih}

Terima kasih kepada para narasumber yang bersedia untuk diwawancarai serta para ahli. Pembimbing peneliti Eko Harry Susanto, Dr., M.Si. dan Nigar Pandrianto, S.Sos., M.Si. yang membantu peneliti dalam mengupas fenomena yang terjadi dalam dunia komunikasi khususnya budaya.

\section{Daftar Pustaka}

Herdiansyah, Haris. (2014). Metodologi Penelitian Kualitatif: untuk Ilmu-Ilmu Sosial. Jakarta: Salemba Humanika.

Liliweri, Alo. (2003). Makna Budaya Dalam Komunikasi Antar Budaya. Yogyakarta: LkiS.

Littlejohn, Stephen W., \& Foss, Karen A. (2009). Teori Komunikasi: Theories of Human Communication. Jakarta: Salemba Humanika.

Moleong, Lexy. (2009). Metode Penelitian Kualitatif. Bandung: PT Remaja

Rosdakarya. 
Mulyana, Deddy. (2010). Ilmu Komunikasi: Suatu Pengantar. Bandung: PT Remaja Rosdakarya.

Putra, Dedi Kurnia Syah. (2016). Komunikasi Lintas Budaya: Memahami Teks Komunikasi, Media, Agama dan Kebudayaan Indonesia. Bandung: Simbiosa Rekatama Media.

Rakhmat, Jalaluddin. (2012). Psikologi Komunikasi. Bandung: PT Remaja Rosdakarya.

Samovar, L. A., Porter, R. A., \& McDaniel, E. R. (2010). Komunikasi Lintas Budaya (7th ed.). Jakarta, Indonesia: Salemba Humanika.

Susanto, Eko Harry. (2018). Komunikasi Manusia: Teori dan Praktek dalam Penyampaian Gagasan. Jakarta: Mitra Wacana Media.

Tamburian, H. (2018). Komunikasi Lintas Budaya Masyarakat Dayak Dalam Menjaga Kerukunan Hidup Umat Beragama. Jurnal Komunikasi, 10(1), 77, 86.

West, R., \& Lynn H. Turner. (2008). Pengantar Teori Komunikasi. Jakarta: Salemba Humanika. 